\title{
FACTORS OF PERSON'S SELF-DETERMINATION AND PSYCHOLOGICAL WELL-BEING
}

\section{Serdiuk L. Z.}

\section{INTRODUCTION}

The problem of an individual's self-determination and psychological well-being belongs to the actual now positive psychology, initiated by M. Seligman and M. Csikszentmihalyi ${ }^{1}$ and drawing attention of the psychological science to development of positive components of human psyche rather than to correction of its negative components. The growth of stress inducing factors in modern society actually creates the demand for studies that can identify factors supporting an individual's positive functioning, development of his/her personal potential, certainty of his/her life goals, prospects, values and autonomy. The social effect is that such studies can help improve the quality of an individual's life, reveal and actualize of his/her internal resources, which support his/her autonomy of choice and counteract negative impacts of the environment.

Today, the theory of self-determination is one of the major scientific approaches to studying the motivation of human behaviour, an individual's personal development and psychological well-being. In defining the basic concepts of the theory of self-determination, we should note that its most essential element is the ideas of humanistic psychology, namely, the idea on existence of an individual's innate abilities and capabilities for a healthy and high-fledged life.

The term of "psychological well-being" appeared in the scientific psychology also in connection with research on the states of positive human functioning; psychological well-being was the key idea in the works of C. Riff ${ }^{2}, \mathrm{~S}$. Lyubomirsky ${ }^{3}$ and others. The desire for positive

${ }^{1}$ Seligman M.E., Csikszentmihalyi M. Positive psychology. American psychologist. 2000. Vol. 55. N 1. P. 5-14.

${ }^{2}$ Ryff C.D, Singer B. The contours of positive human health. Psychological Inquiry. 1998. Vol. 9. P. 719-727.

${ }^{3}$ Lyubomirsky S, Sheldon K.M., Schkade D. Pursuing happiness: The architecture of sustainable change. Review of General Psychology. 2005. Vol. 9. P. 111-131. 
functioning and the sense of well-being are ones of the main driving forces of personal growth and an important condition for the quality of an individual's life, his/her self-realization and self-determination. Thus, the problems of self-determination and psychological well-being are linked as two sides of one medal - an individual's self-determination creates conditions for high-result achievements at activities and, thus, it strengthens his/her psychological well-being.

The research purpose is to determine the psychological nature of the phenomena of self-determination and psychological well-being, their interrelations, factors and components.

155 people participated in the research: 100 university students and 55 working professionals (Kyiv), 41 men and 114 women. Age of the respondents was from 18 to 44 years. The following psychological diagnostic techniques were used: Purpose-in-Life Test (PIL) of J. Krambo, L. Maholika (in D.O. Leontiev's adaptation); Hardiness Test of S. Maddy (adapted by D.O. Leontiev, A.I. Rasskazova); Ryff's Scales of Psychological Well-being (the modified version of T.D. Shevelenkova, P.P. Fesenko); E.M. Osin's Self-Determination Test; the questionnaire for self-attitude of V.V. Stolin, S.R. Pantileev; Shostrom's Personal Orientation Inventory (the adaptation of Yu.E. Alyoshina, L.Ya. Gozman, M. Zagika and M.V. Kroz); SelfEfficacy Scale of R. Schwarzer and M. Jerusalem. The obtained data processing was carried out using the computer program for statistical data processing SPSS Statistics 21.0.

\section{Self-determination and personality formation and development}

At self-determination ${ }^{4}$ analysis, the problem of an individual's selfactivity and his/her ability to choose independently own way of selfdevelopment is put in the foreground. Therefore, important practical tasks, solved within this the theory, are determination of conditions and factors that can promote personal development and searching for resources associated with development of internally motivated behaviour. Such an individual's internal evaluation, his/her motivation and corresponding behaviour are consistent with the personal internal

${ }^{4}$ Deci E.L., Ryan R.M. Self-Determination Theory: A macrotheory of human motivation, development, and health. Canadian Psychology. 2008. No. 49, P. 182-185. 
tendency to actualization and the organic process of evaluation and support the individual's well-being (eudemony), which is one of the goals of positive psychology 5 . Therefore, the main practical tool of the positive psychology is coaching, which means development of those personality aspects that are underdeveloped ${ }^{6}$.

In this context, the theory of self-determination and personal autonomy of E. Deci, R. Ryan ${ }^{7}$ is classical. The theory of selfdetermination is a macro-theory of human motivation, developed from a large number of the studies of internal motivation in various organizations and areas of life. Internal motivation is people's spontaneous motives to be curious and interested in something, to search for challenges, and to develop or implement their skills and knowledge, even without apparent rewards.

Self-determination as a scientific problem is developed within the framework of many psychological approaches, such as: the existentially oriented theory of freedom (V. Frankl, R. May), the theory of subjectivity (R. Harre), the theory of self-efficacy (A. Bandura), the theory of self-actualization (A. Maslou), the time perspective (J. Nuttin), the theory of "flow" (M. Seligman, \& M. Csikszentmihalyi), etc.

The problems of personality formation, fulfilment of personal capabilities and the achievement of Self ("to be oneself") are the main subjects of the theories of personal growth ${ }^{8}$. The studies, carried out on the basis of the theory of self-determination ${ }^{9}$, show that internal motivation can predict an individual's learning achievements, productivity, creativity, optimal development and psychological wellbeing. Indeed, such search states of the individual actuate searches for novelty and challenges and, moreover and are a tool to discover novelty and to open up new challenges. That is, internally motivated searching behaviour, above all, is backed by interests and inclinations, rather than

${ }^{5}$ Linley P.A., Joseph S. Toward a theoretical foundation for positive psychology in practice. Positive psychology in practice. Hoboken, NJ: John Wiley \& Sons, 2004. P. 713-731.

6 Чиксентмихайи М. Поток : психология оптимального переживания. М. : Смысл : Альпина нон-фикшн, 2011. $461 \mathrm{c.}$

7 Deci E.L., Ryan R.M. Intrinsic motivation and self-determination in human behavior. University of Rochester. Rochester, New York : Plenum Press, 1985. 375 p.

${ }_{8}^{8}$ Маслоу А. Мотивация и личность. Издательство: Питер, 2012. 352 с.

${ }^{9}$ Ryan R.M., Deci E.L., Grolnic W.S. Autonomy, relatedness, and the Self: their relation to development and psychopathology. Developmental psychopathology. 1995. Vol. 1. P. 618-655. 
by a decrease in anxiety ${ }^{10}$; and self-determination is not only ability, but also a need, a main innate predisposition that actuates an individual's behaviour leading to development of skills for flexible interaction with the social environment. Thus, E. Deci and R. Ryan ${ }^{11}$ suggested that internal motivation is a function of psychological growth throughout life, based on the basic psychological needs in competence and autonomy, and, of course, not excluding external motivation, which should be taken into account in the system with other determinants. External motivation varies depending on its value internalization and integration. Internalisation means how well the value is perceived, and integration explains the process of transition from external regulation of an individual's behaviour to self-regulation ${ }^{12}$. Accordingly, the least internationalized form of behavioural regulation is the external form and behaviour, in this case, is aimed at obtaining certain rewards or avoiding certain negative unpredictable outcomes. Thus, development is a way of mutual actuation of internal potentials, interests and the unification of knowledge, values and regulatory mechanisms that leads to their harmonization $^{13}$.

The term of "internalization" is used for description of the process, within which an individual's behaviour becomes relatively more autonomous, and the theory of self-determination distinguish three personal needs critical for supporting this process and developing an individual's optimal motivation and personal well-being: the needs for autonomy, competence and relatedness. Thus, the possibility to meet the needs for autonomy, competence and relatedness with other people provides freedom of activities, self-organization and self-determination.

In the past 10-15 years, the number of studies based on the theory of self-determination in the context of health has increased, including studies on health-preserving environments and behaviour. The results of

${ }^{10}$ Ryan R.M., Deci E.L. Self-determination theory: Basic Psychological Needs in Motivation Development and Wellnessi. New York, NY: Guilford Press, 2017. 756 p.

11 Deci E.L., Ryan R.M. Intrinsic motivation and self-determination in human behavior. University of Rochester - Rochester, New York : Plenum Press, 1985. 375 p.

${ }^{12}$ Deci E.L., Ryan R.M. The "what" and "why" of goal pursuits: Human needs and the self-determination of behavior. Psychological Inquiry. 2000. No. 11. P. 227-268.

${ }^{13}$ Ryan R.M., Deci E.L., Grolnic W.S. Autonomy, relatedness, and the Self: their relation to development and psychopathology. Developmental psychopathology. 1995. Vol. 1. P. 618-655. 
these studies show important role of autonomous self-regulation and support of the needs for various aspects of mental and physical health.

Autonomous self-regulation is especially important for health promoting behaviour ${ }^{14}$, since it regulates more effectively an individual's efforts, persistence and stability. In this sense, the possibility to meet the needs for autonomy, competence and relatedness provides freedom of activity and self-organization. Consequently, selfdetermination means a sense of freedom in relation to both the forces of the external environment and the internal forces of an individual. Therefore, the concept of autonomy is the key concept for this theory. An autonomous person is a person acting as an agent, based on a deep sense of Self. Within the framework of the theory of self-determination, competence and autonomy are seen as important elements in people's active tendencies to search for challenges, to be interesting and interested, as well as to develop and express their creative talents: when these needs are supported, the internal motivation appears, but when they are frustrated, internal motivation is undermined.

The conceptual framework for self-determination as an ability to define and achieve goals is also based on knowledge and selfevaluation"15 and the role of the social context in maintaining or disrupting an individual's optimal motivation. Competence is related to the sense of efficiency, growing skills in actions that are optimally difficult and can further develop personal abilities. Therefore, according to A. Bandura, the author of the socio-cognitive theory of personality and his/her behaviour regulation, there is no more substantial mechanism of subjectivity, and, therefore, self-determination, than the belief in own self-efficacy ${ }^{16}$.

Actually, an individual's self-efficacy, as a belief in own ability to organize and perform actions, and his/her self-attitude, which largely determines the formation of ideas about the world and Self (provides prediction of own social effectiveness and attitudes from others, regulates interpersonal relations and goal formulation and achievement),

${ }^{14}$ Ryan R.M., Deci E.L. Self-determination theory: Basic Psychological Needs in Motivation Development and Wellnessi. New York, NY: Guilford Press, 2017. 756 p.

${ }^{15}$ Field S., Hoffman A. Development of a model for self-determination. Career Development for Exceptional Individuals. 1994. Vol. 17. P. 159-169.

${ }^{16}$ Bandura A. Self-Efficacy Mechanism in Human Agency. American psychologist. 1982. Vol. 37. No. 2. P. 122-147. 
in line with the social status and personal attitudes to the outside world, constitute the content of the "personality - social world" system and therefore they are extremely necessary for achievement of expected results. If people are not sure about their ability to get the desired results, they will not be determined to act.

The capabilities, important for an individual's self-determined behaviour, also include the abilities to choose and to solve problems, self-defence, internal locus of control, self-awareness and selfknowledge $^{17}$. Existence of goals and meanings for an individual's perspective future as certain psychological foundations of his/her selfrealization should also be noted. Current studies in line with the theory of self-determination confirm the existing link between success and autonomy and confirm the hypothesis that success is more likely if one's own goals are inalienable and designed to meet his/her basic needs ${ }^{18}$.

Summarizing the above, the key aspects of the problem of an individual's self-determination can be determined:

1. An individual's awareness on his/her capabilities and prediction of his/her future allows him/her to get rid of the deterministic influence of the lower levels of regulation, and their transcendence gives relative freedom and high potential for self-determination development.

2. The category of freedom has certain external and internal resources, the totality of which determines the degree of an agent's freedom in a particular situation; value-semantic mediation of an individual's self-determination and his/her system of values determine the distinction of positive "freedom for" from the negative "freedom from".

3. The need for self-determination involves an individual's desire to independently control his/her actions and behaviour, and also to be an independent initiator.

Thus, self-determination is understood as an individual's capability to make choices, to perceive Self but not reinforcements, incentives or some other forces that can also act as determinants of his/her behaviour.

17 Wehmeyer M. L. Self-determination and the education of students with disabilities. 2002. ERIC EC Digest \#E632. Retrieved from http://www.hoagiesgifted.org/eric/ e632.html

${ }^{18}$ Koestern R., Hope N. A self-determination theory approach to goals. 2014. In M. Gagne (Ed.) The Oxford Handbook of Work Engagement, Motivation, and SelfDetermination Theory.doi:10.1093/oxfordhb/9780199794911.001.0001. 
At the same time, an individual, his/his beliefs, desires and aspirations are the source and causes for his/her behaviour, and successes or failures in actions are explained by the effectiveness of self-regulation.

On the basis of the empirical research results, we have determined the psychological factors and components of an individual's selfdeterministic behaviour, as well as predictors of personal development.

The results of the performed correlation analysis are presented in the tables 1-3 (only significant correlation are shown); they indicate that the indicators of an individual's self-determination are related to the indicators of meaningful life orientations, psychological hardiness, self-efficacy, self-attitude and self-actualization of the individual.

Table 1

\section{Correlation between self-determination indicators and meaningful life orientations}

\begin{tabular}{|c|c|c|c|c|c|c|c|c|c|}
\hline & 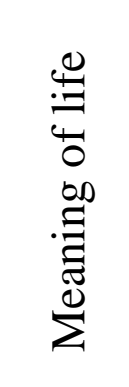 & 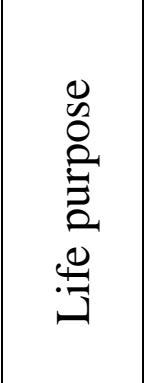 & 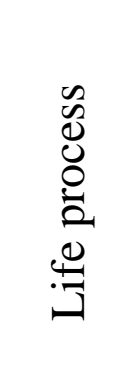 & 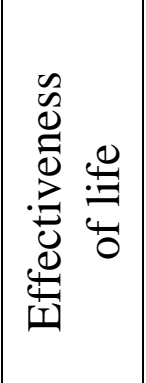 & 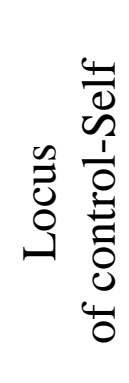 & $\begin{array}{l}\bar{O} \\
\text { 泀 } \\
\end{array}$ & 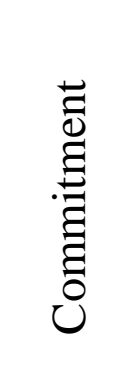 & 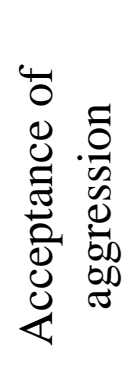 & 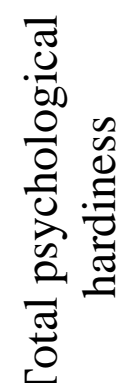 \\
\hline $\begin{array}{l}\text { Self- } \\
\text { expression }\end{array}$ &, $367^{* *}$ &, $626^{* *}$ &, $542^{* * *}$ &, $622^{* *}$ &, $399^{* * *}$ &, $402^{* *}$ &, $394^{* *}$ &, $463^{* *}$ &, $446^{* *}$ \\
\hline Autonomy & ,292* &, $720^{* * *}$ &, $647^{* * *}$ &, $557^{* * *}$ & $297^{*}$ &, $555^{* *}$ &, $542^{* *}$ & $388^{* *}$ &, $555^{* *}$ \\
\hline
\end{tabular}

** the correlation is significant at the level of 0.01 ;

* the correlation is significant at the level of 0.05

From the data presented in Table 1, we can conclude that, in general, the psychological basis of an individual's self-determination is his/her awareness of life goals, his/her holistic perception of the life path, active participation in social life, self-acceptance; the significant correlation with psychological hardiness means that an individual's self-determination is important for health preservation, for an optimal level of work capacity and activity, especially in stressful situations. 
Table 2

Correlation between self-determination indicators and self-efficacy and self-attitude

\begin{tabular}{|c|c|c|c|c|c|c|c|c|c|}
\hline & 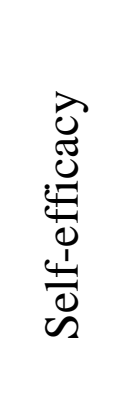 & 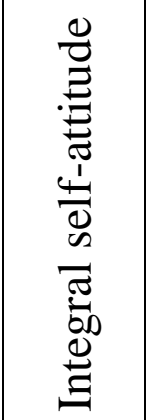 & 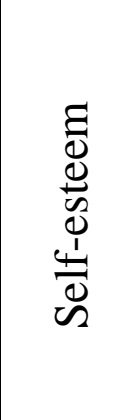 & 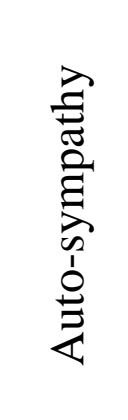 & 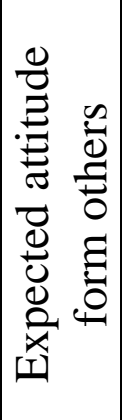 & 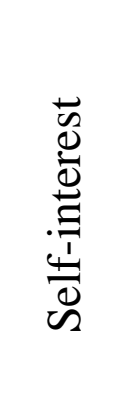 & 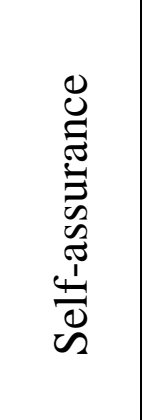 & 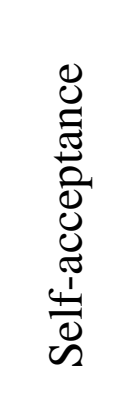 & 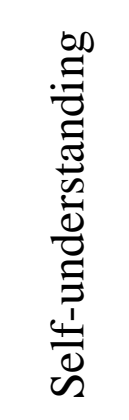 \\
\hline $\begin{array}{l}\text { Self- } \\
\text { expression }\end{array}$ &, $356^{*}$ &, $508^{* * *}$ &, $338^{*}$ &, $314^{*}$ & ,198 & , 125 &, $530^{* *}$ &, $527^{* *}$ &, 146 \\
\hline Autonomy &, 180 &, $527^{* * *}$ &, $621^{* * *}$ &, $465^{\text {** }}$ & ,313* & $387^{* *}$ & $395^{* *}$ &, $550^{* * *}$ & $464^{* *}$ \\
\hline
\end{tabular}

The data in the Table 2 indicates that an individual's selfdetermination is related to the individual's ability to independently regulate own behaviour, to create conditions and circumstances for meeting personal needs and goals, trusting relations with the environment, confidence in own ability to achieve the goals and selfacceptance.

Table 3

Correlation between self-determination indicators and self-actualization

\begin{tabular}{|c|c|c|c|c|c|c|c|c|c|}
\hline & 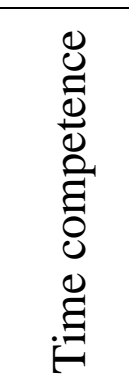 & 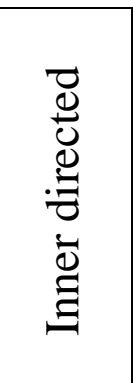 & 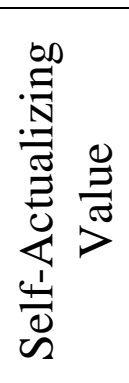 & 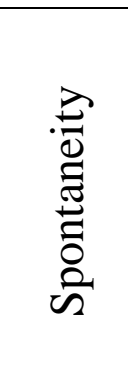 & 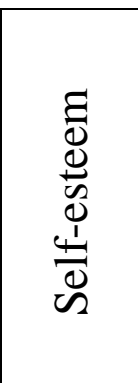 & 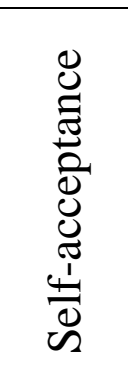 & 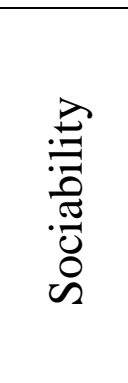 & 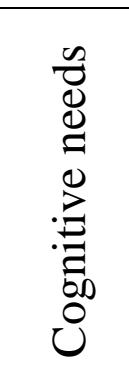 & 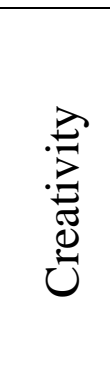 \\
\hline $\begin{array}{l}\text { Self- } \\
\text { expression }\end{array}$ &, $315^{*}$ &, $305^{*}$ &, $460^{* *}$ & 206 &, $370^{* * *}$ & 160 &, $285^{*}$ &, $377^{* *}$ & ,331* \\
\hline Autonomy & $427^{* *}$ & $406^{* *}$ &, $583^{* *}$ &, $439^{* * *}$ &, $379^{* *}$ & ,354* & ,291* & ,251 & , 150 \\
\hline
\end{tabular}

The data presented in Table 3 also shows that an individual's selfdetermination is related to independence and self-dependence, the desire 
for personal growth, awareness of the goals for own future, integrity and the coherence of life path events.

By regression analysis, we have determined independent variables that are the most significant for self-determination prediction, that is an individual's subjective experience of how much he/she determines his/her life path and how much his/her life corresponds to his/her will.

You can forecast the self-determination index using four models (Table 4).

Table 4

Regression models ${ }^{\mathrm{e}}$

\begin{tabular}{|c|c|c|c|c|}
\hline Model & $\mathrm{R}$ & R-square & Adjusted R-square & $\begin{array}{c}\text { Std. estimation } \\
\text { error }\end{array}$ \\
\hline 1 & $0.65^{\mathrm{a}}$ & 0.42 & 0.41 & 3.82 \\
\hline 2 & $0.67^{\mathrm{b}}$ & 0.47 & 0.46 & 3.73 \\
\hline 3 & $0.72^{\mathrm{c}}$ & 0.56 & 0.49 & 3.72 \\
\hline 4 & $0.73^{\mathrm{d}}$ & 0.63 & 0.51 & 3.64 \\
\hline
\end{tabular}

a Predictors: (const) life purpose

b. Predictors: (const) life purpose, autonomy

c. Predictors: (const) life purpose, autonomy, personal growth

d. Predictors: (const) life purpose, autonomy, personal growth, risk acceptance

e. Dependent variable: self-determination

The fourth model explains $63 \%$ dispersion, so we have chosen it for further description. Consequently, an individual's self-determination can be predicted through his/her life purpose, autonomy, personal growth, risk acceptance.

In general, the obtained results show life goals and meanings, the internal locus of control, personal autonomy are of great importance of self-determination of an individual's behaviour, which means an individual's ability to self-determinate his/her positions and to determine and regulate independently his/her live.

\section{Personality factors of psychological well-being}

The term of "psychological well-being" appeared in the scientific psychology in connection with research on the states of optimal human functioning. The desire for a positive functioning and a feeling of wellbeing is one of the main driving forces of personal growth and an 
important condition for the quality of an individual's life, so the problem of its acquisition and support is the subject of psychological research done by S. Lyubomirsky, R.M. Ryan, E.L. Deci, C.D. Ryff, M.E. Seligman, M. Csikszentmihalyi and others.

The term of "psychological well-being" is associated with a number of related concepts: "happiness", "mental health", "positive lifestyle", "emotional comfort", "quality of life", "life satisfaction", "subjective well-being" and others. Such a variety of terms does not only indicate a significant interest in various aspects of well-being, but also shows conceptual differences in the definition of its essence and factors.

The theoretical basis for understanding of psychological well-being and its importance in personal self-realization was laid by the research of C. Riff $^{19}$, S. Lyubomirsky ${ }^{20}$ and others, whose works studied an individual's subjective well-being, which includes the concepts of happiness, satisfaction with life, positive emotionality, psychological health, etc.

The studies of subjective well-being began with the works of H. Cantril, E. Diener, N. Bradburn, M. Jahoda, which in fact identified psychological well-being with mental health, happiness, the absence of adverse symptoms. Describing the criteria for mental health, the researchers focused on the mental balance and harmony of the psyche and its adaptive abilities, the ability to adequately change behaviour in accordance with changes in the environment and with the accepted moral and ethical norms, feelings of affection and responsibility towards relatives, the ability to realize own life plans. Thus, R.M. Ryan, E.L Deci, believe that the link between physical health and psychological well-being is apparent ${ }^{21}$. Diseases often cause functional constraints that reduce the possibilities for life satisfaction. Therefore, subjective psychological hardiness correlates not only with such indicators of psychological well-being as autonomy and positive relationships with others, but also with physical symptoms.

19 Ryff C.D., Singer B. The contours of positive human health. Psychological Inquiry. 1998. Vol. 9. P. 719-727.

${ }^{20}$ Lyubomirsky S., Sheldon K.M., Schkade D. Pursuing happiness: The architecture of sustainable change. Review of General Psychology. 2005. Vol. 9. P. 111-131.

${ }^{21}$ Deci E.L., Ryan, R. The "What" and "Why" of Goal Pursuits : Human Needs and the Self-Determination of Behavior personality. Psychological Inquiry. 2000. Vol. 11. N. 4. P. 227-268. 
C. Riff contributed significantly to research on psychological wellbeing, offering its multi-factorial structure of six components, as a manifestation of positive psychological functioning: self-acceptance, personal growth, purpose in life, environmental mastery, autonomy, positive relations with others.

All understanding approaches to psychological well-being developed for today, according to R. Ryan, can be divided into two main directions: hedonistic and eudemonic. Representatives of the hedonistic school (N. Bradburn, E. Diener and others) understand psychological well-being as a personal state achieved with satisfaction of needs in various spheres of life; for example, the three-component model of subjective well-being of E. Diener consists of life satisfaction, absent negative affects and present positive emotions. Eudemonistic models include more components than hedonistic ones and their constructs have other meanings. Such is the model of psychological well-being proposed by C.D. Ryff ${ }^{22}$. Psychological well-being, within the framework of the eudemonistic approach, is understood as the result of revealed creative potential, optimal functioning or realization of an individual's own nature. We should especially note the theory of self-determination of R.M. Ryan and E.L. Deci ${ }^{23}$, based on the concept of the basic human needs: selfdetermination, competence, positive relations. The authors note that need satisfaction is directly related to the actual social context: if the environment contributes to their satisfaction, psychological well-being and hardiness grow, otherwise, well-being decreases. This model defines the factors stimulating the innate human potential and determining personal growth, integration and health, so processes and conditions can be determined that promote healthy development and the effective functioning of individuals, groups and communities.

As separate approaches, there are also the studies on "quality of life", where well-being is viewed in a somewhat broader sense than that in hedonistic and eudemonistic models and includes the physical,

22 Ryff C.D., Singer B. The contours of positive human health. Psychological Inquiry.1998. Vol. 9. P. 719-727.

${ }^{23}$ Ryan R.M., Deci E.L. Self-determination theory: Basic Psychological Needs in Motivation Development and Wellnessi. New York, NY: Guilford Press, 2017. 756 p. 
psychological and social aspects of an individual's functioning (S. Lyubomirsky ${ }^{24}$, M.E. Seligman, M. Csikszentmihalyi ${ }^{25}$ and others).

The above-described approaches can be divided into direct, aimed at life satisfaction increasing, in order to develop more adaptive forms of behaviour, relations and goals, and indirect, aimed at studying the nature of stressors and their determinants (for example, poor support of the environment, pessimistic attributive style) in order to increase life satisfaction.

If we try to determine links between the theory of selfdetermination of R.M. Ryan and E.L. Deci and the theory of psychological well-being C.D. Ryff, then it is in the fact that theories are based on the concept of basic human needs. Need satisfaction is directly related to the actual social context: if the environment contributes to their satisfaction, well-being and psychological hardiness grow, otherwise, well-being is reduced. Thus, the theory of self-determination rise the problem of an individual's psychological well-being to the existential level manifested in the existence of his/her life.

Thus, psychological well-being can be defined as an integral indicator of an individual's orientation toward fulfilment of the main components of positive functioning, as well as the degree of this orientation implementation, which is subjectively expressed in the sense of happiness, satisfaction with his/herself and his/her life. As an integral personal construct, psychological well-being is dynamic and therefore it is an individual's motivational parameter, which expressiveness depends on realism, structuring, integrity (consistency of the past, present and future) of the system of the individual's attitudes and life perspective, including his/her goals, plans, values and aspirations.

As for research on the psychological well-being factors, they are associated with such personal characteristics as extraversion, optimistic attributive style and emotional stability ${ }^{26}$; academic and

${ }^{24}$ Lyubomirsky S., Sheldon K.M., Schkade D. Pursuing happiness: The architecture of sustainable change. Review of General Psychology. 2005. Vol. 9. P. 111-131.

${ }^{25}$ Seligman M.E., Csikszentmihalyi M. Positive psychology. American psychologist. 2000. Vol. 55. N 1. P. 5-14.

26 Rigby B.T., Huebner E.T. Do causual attributions mediate the relationship between personality characteristics and life satisfaction in adolescence? Psychology in the Schools. 2005. Vol. 42. P. 91-99. 
general achievements ${ }^{27}$. The personal potential of psychological wellbeing depends significantly on life circumstances, in particular on social support ${ }^{28}$.

There are the following social-psychological factors of psychological well-being: safety and comfort of the home environment; an atmosphere of love characterized by family joy, proximity and harmony; openness and trust in interpersonal relations; parental control and inclusion in the lives of their children; sense of importance in the family; family support for children's relations with people and their activities outside the family ${ }^{29}$.

Different views of researchers studying psychological well-being concerning its essence and components are conditioned, first of all, by the fact that they are evaluated by an individual from the standpoint of his/her values and goals. Since the latter are always individual, then there cannot be any universal structure of psychological well-being. In this case, it is advisable to study the factors influencing a subjective sense of satisfaction (existential experience of the attitude toward one's own life).

By analyzing the factors of psychological well-being and performing the factor analysis (the method of principal components) of the empirical data with the sample of respondents having high psychological well-being, we distinguished 6 factors, which contribution into the total data dispersion is $71,4 \%$ (Table 5). The indicator of the sample selective adequacy is 0.65 , and Sig of Bartlett's test of sphericity is less than 0.5 , so we can assume that the performed factor analysis is reliable.

This characteristic of factors completely explains the origins of psychological well-being of students, whose motivation is focused on self-realization, personal autonomy, self-expression, self-acceptance, realization of their nature, revealed creative potential, positive relations with others, faith in their effectiveness, etc.

${ }^{27}$ Suldo S.M, Shaffer E.S., Riley K. A social-cognitivebehavioral model of academic predictors of adolescents' life satisfaction. School Psychology Quarterly. 2008. Vol. 23. P. 56-69.

${ }^{28}$ Gilman R., Huebner E.S. Characteristics of adolescents who report very high life satisfaction. Journal of Youth and Adolescence. 2006. Vol. 35. P. 311-319.

${ }^{29}$ Joronen K., Astedt-Kurki P. Familial contribution to adolescent subjective wellbeing. International Journal of Nursing Practice. 2005. Vol. 11. P. 125-133. 
Factors of psychological well-being

\begin{tabular}{|c|c|c|}
\hline Factor & $\begin{array}{c}\text { Factor } \\
\text { load }\end{array}$ & \multicolumn{1}{|c|}{ Parameters constituting factors } \\
\hline 1 & $23,1 \%$ & $\begin{array}{l}\text { Commitment }(, 841), \text { locus of control - Self (,840), } \\
\text { self-expression (,784), life purpose (,771), meaning of } \\
\text { live (,763), locus of control - life (,758), autonomy } \\
(, 732), \text { control (,725), environmental mastery (,714), } \\
\text { balance of affect (-,627), value orientations (,594), } \\
\text { self-esteem (,586), self-understanding (,576), self- } \\
\text { acceptance (,563) }\end{array}$ \\
\hline 2 & $14,2 \%$ & $\begin{array}{l}\text { Auto-sympathy (-,781), inner directed (,728), focus on } \\
\text { the present (,636), personal grows (,628), cognitive } \\
\text { needs (,596), positive relations (-,515), acceptance of } \\
\text { aggression (,408) }\end{array}$ \\
\hline 3 & $11,2 \%$ & $\begin{array}{l}\text { Flexible behaviour (,668), spontaneity (,596), synergy } \\
(, 529), \text { creativity (,482), sensitivity (,468) }\end{array}$ \\
\hline 4 & $9,1 \%$ & $\begin{array}{l}\text { Expected attitudes from other (,637), life sense (,531), } \\
\text { self-assurance (-,526), sociability (,512), fixation } \\
(, 462)\end{array}$ \\
\hline 5 & $7,5 \%$ & $\begin{array}{l}\text { Risk acceptance (,590), self-interest (,569), } \\
\text { purposefulness (,561), open system (,540), nature of a } \\
\text { man (,489) }\end{array}$ \\
\hline 6 & $6,3 \%$ & $\begin{array}{l}\text { Time competence (,557), self- efficacy (,540), } \\
\text { persistence (,528) }\end{array}$ \\
\hline
\end{tabular}

Based on the factor contents, the respondents, in general, can be characterized as capable to self-regulate their own behaviour; to create conditions and circumstances appropriate for meeting their personal needs and achieving their goals; aspiring for personal growth; understanding the goals of their future, having trusting relations with the environment, understanding that relations are built on mutual actions; they are sufficiently independent and self-dependent, confident in their ability to achieve their goals.

With the data in Table 5, we can analyze and interpret the content of the determined factors, which, in general, do not contradict the factors determined by C. Riff, but nevertheless have somewhat wider meanings:

Factor 1. This factor means an individual's autonomy and independence, his/her ability to control and influence his/her life. It 
shows expressed personal orientation on oneself, positive assessment of all aspects of the personality. Such people are relatively independent in their actions, they want to be guided in their lives by their own goals, beliefs, attitudes and principles, they are free to choose and not dependent on external influence.

Factor 2. This factor means a prominent aspiration for something new, unknown, developed intuition and, at the same time, expectations of support and a positive assessment from others.

Factor 3. The factor characterizes an individual's flexibility as an agent implementing his/her values into his/her behaviour and interactions with others, the ability to respond quickly and adequately to different life situations in accordance with their needs and feelings, sometimes even those that arise spontaneously and directly.

Factor 4. This factor describes an individual's ability to establish emotionally rich contacts with people, such relations are important for $\mathrm{him} /$ her because of their values and meanings; expectation of a positive attitude from others.

Factor 5. This factor characterizes an individual's ability to experience his/her life in accordance with his/her desires, needs and values; it is an experience of self-identity, a holistic, realistic view on own life, openness to new experience, spontaneity and naturalness of experiences.

Factor 6. This factor means an individual's ability to integrated perception of the life path, to link the past, present and future, persistence in goal achievement, faith in activity effectiveness.

Table 6 presents the results of regression analysis by which we can predict the indicator of students' psychological well-being.

The data in Table 6 show that the four models can predict the psychological well-being. Consequently, based on the fourth model, which explains $78.9 \%$ of variances, we have found that the predictors having the greatest impact in the predictive model for psychological well-being are: commitment, acceptance of aggression, self-esteem, and expected attitude from others.

The students' psychological well-being has a complex and multifactor personal determination, where the following factors are the most important: personal autonomy, self-expression, realization of own nature, revealed creative potential, purposefulness, positive relationships with others and self-efficacy. 
Regression models

\begin{tabular}{|c|c|c|c|c|}
\hline Model & $\mathrm{R}$ & $\mathrm{R}^{2}$ & Adjusted $\mathrm{R}^{2}$ & St. estimation error \\
\hline 1 &, $782^{\mathrm{a}}$ &, 612 &, 609 & 24,439 \\
\hline 2 &, $843^{\mathrm{b}}$ &, 711 &, 707 & 21,149 \\
\hline 3 &, $872^{\mathrm{c}}$ &, 760 &, 755 & 19,354 \\
\hline 4 &, $888^{\mathrm{d}}$ &, 789 &, 782 & 18,245 \\
\hline
\end{tabular}

a. Predictors: (Const) commitment

b. Predictors: (Const) commitment, acceptance of aggression

c. Predictors: (Const) commitment, acceptance of aggression, self-esteem

d. Predictors: (Const) commitment, acceptance of aggression, self-esteem, expected attitude from others

e. Dependent variable: psychological well-being

\section{CONCLUSIONS}

The following components can be determined in the structure of an individual's self-determination and psychological well-being: goals, values, meanings, awareness of life path, prospect of the future; motivation for self-development and self-realization; self-efficacy, selfattitude and autonomy, understanding of own potential and faith in own capabilities; the ability to consciously control and evaluate own achievements and prospects, inclusion in social life.

In general, an individual's successful self-realization and psychological well-being is determined by his/her desire for selfdevelopment and own potential revelation, assessment of personal resources as sufficient for success and holistic perception of own life path, availability and realism of life goals, integration of the past, present and future in personal psychological life space.

The main factors of an individual's self-determination, successful self-realization and psychological well-being are: awareness of goals, meanings, prospects of their future, motivation of self-development and self-realization, understood inner potential, belief in own capabilities, personal autonomy, the ability to consciously control and evaluate achievements and prospects. A significant barrier to self-determination is absence of clear and unequivocal notions about own future, as well as absence of understanding of the ways and means for life goal achievement. 
Psychological well-being is a necessary condition for an individual's formation as an active agent and is an integral part of motivation for self-realization and self-determination.

An individual's psychological well-being can be supported by actuated internal resources, which means understanding of reserves for full-scale realization in the present and the possibilities of developing of the self-determination abilities in the future.

\section{SUMMARY}

The article analyzes the phenomena of personaliti's selfdetermination and psychological well-being. It reveals the personal potential of self-determination of person's behavior. The selfdetermination structure includes the following components: goals, values, meanings, awareness of own life journey, perspective of the future; motivation for self-development and self-realization; personal self-efficiency, self-attitude and autonomy; understanding of own powers and confidence in own capabilities; conscious control and realistic assessment of own achievements and prospects, involvement into the social life.

The main factors of self-determination, successful self-realization and personal psychological well-being are: understanding of own purposes, meanings, perspective of own future; existence of motivation for self-development and self-realisation, understanding of own powers and confidence in own capabilities, personal autonomy, and the ability to control consciously and to assess own achievements and prospects.

It substantiates that self-determination of personal development is the psychological foundation and prerequisite for personal selfrealization. Successful self-realisation and personal psychological wellbeing is determined by existence of personal desire for self-development and personal power revealing, evaluation of own personal powers as sufficient to success achievement and holistic perception of life's journey, including existence of realistic life goals. These factors stipulate goal-setting motivation and determine integration of the past, present and future in a personal psychological life space.

It is substantiated that self-determination of personality development is a psychological basis for its self-realization and psychological well-being. 


\section{REFERENCES}

1. Маслоу А. Мотивация и личность. Издательство: Питер, $2012.352 \mathrm{c}$.

2. Чиксентмихайи М. Поток : психология оптимального переживания. М. : Смысл : Альпина нон-фикшн, 2011. 461 с.

3. Bandura A. Self-Efficacy Mechanism in Human Agency. American psychologist. 1982. Vol. 37. No. 2. P. 122-147.

4. Deci E.L., Ryan R.M. Intrinsic motivation and selfdetermination in human behavior. University of Rochester. Rochester, New York : Plenum Press, 1985. 375 p.

5. Deci E.L., Ryan R.M. Self-Determination Theory: A macrotheory of human motivation, development, and health. Canadian Psychology. 2008. No. 49, P. 182-185.

6. Deci E.L.,Ryan, R. The "What" and "Why" of Goal Pursuits : Human Needs and the Self-Determination of Behavior personality. Psychological Inquiry. 2000. Vol. 11. N. 4. P. 227-268.

7. Field S., Hoffman A. Development of a model for selfdetermination. Career Development for Exceptional Individuals. 1994. Vol. 17. P. 159-169.

8. Gilman R., Huebner E.S. Characteristics of adolescents who report very high life satisfaction. Journal of Youth and Adolescence. 2006. Vol. 35. P. 311-319.

9. Joronen K., Astedt-Kurki P. Familial contribution to adolescent subjective well-being. International Journal of Nursing Practice. 2005. Vol. 11. P. 125-133.

10. Koestern R., Hope N. A self-determination theory approach to goals. 2014. In M. Gagne (Ed.) The Oxford Handbook of Work Engagement, Motivation, and Self-Determination Theory. doi:10.1093/oxfordhb/9780199794911.001.0001.

11. Linley P.A., Joseph S. Toward a theoretical foundation for positive psychology in practice. Positive psychology in practice. Hoboken, NJ: John Wiley \& Sons, 2004. P. 713-731.

12. Lyubomirsky S, Sheldon K.M., Schkade D. Pursuing happiness: The architecture of sustainable change. Review of General Psychology. 2005. Vol. 9. P. 111-131.

13. Rigby B.T., Huebner E.T. Do causual attributions mediate the relationship between personality characteristics and life satisfaction in adolescence? Psychology in the Schools. 2005. Vol. 42. P. 91-99. 
14. Ryan R.M., Deci E.L. Self-determination theory: Basic Psychological Needs in Motivation Development and Wellnessi. New York, NY: Guilford Press, 2017. 756 p.

15. Ryan R.M., Deci E.L., Grolnic W.S. Autonomy, relatedness, and the Self: their relation to development and psychopathology. Developmental psychopathology. 1995. Vol. 1. P. 618-655.

16. Ryff C.D, Singer B. The contours of positive human health. Psychological Inquiry. 1998. Vol. 9. P. 719-727.

17. Seligman M.E., Csikszentmihalyi M. Positive psychology. American psychologist. 2000. Vol. 55. N 1. P. 5-14.

18. Suldo S.M, Shaffer E.S., Riley K. A social-cognitivebehavioral model of academic predictors of adolescents' life satisfaction. School Psychology Quarterly. 2008. Vol. 23. P. 56-69.

19. Wehmeyer M. L. Self-determination and the education of students with disabilities. 2002. ERIC EC Digest \#E632. Retrieved from http://www.hoagiesgifted.org/eric/e632.html

\section{Information about the author:} Serdiuk L. Z.

Dr. of Science (Psychology), Professor, Head of the Laboratory of Psychology of Personality Kostiuk Institute of Psychology of the NAES of Ukraine 2, Pankivska str., Kyiv, 01033, Ukraine 